\title{
Influence of Health Belief Model and Motivation with Prevention of Pulmonary Tuberculosis Transmission in Public Health Center Gurah Kediri Regency
}

\author{
Nanang Muhibuddin ${ }^{1}$, Endah \\ Susanti², Astri Yunita ${ }^{3}$ \\ ${ }^{1}$ STIKes Bhakti Mulia \\ ${ }^{2}$ STIKes Bhakti Mulia \\ ${ }^{3}$ STIKes Bhakti Mulia \\ Email: \\ nanang.dr80@gmail.com
}

Received : March $27^{\text {th }} 2021$

Accepted : April 29 2021

Published : May 20 2021

\begin{abstract}
Tuberculosis is a health problem, both in terms of morbidity and mortality, and the incidence rate of disease or morbidity. This infectious disease is caused by the germ mycobacterium tuberculosis. The purpose of this study is to find out the influence of health belief models and motivation with the prevention of pulmonary tuberculosis transmission. The design used in the study is correlational analytics with a cross sectional method approach. While the sample in this study which is Some people with pulmonary tuberculosis (TB) in Gurah Public Helath Center with BTA (+) as many as 22 respondents. The research instrument used is a questionnaire. Spearman Rho test analysis of the level of significance $(\alpha=$ $0.05)$, so as to be able to answer the purpose of the study.

Based on Spearman Rho correlation statistical test, obtained p 0.001 result for health belief model and p 0.021 , which means that the values p 0.001 and $0.021<0.05$. From the results obtained that $\mathrm{H} 1$ received which means there is an influence of health belief model and motivation with the prevention of pulmonary tuberculosis transmission in Gurah Health Center Kediri Year 2020.

It was concluded that the prevention of transmission of Pulmonary TB disease can be improved reciprocal relationship between health workers, families and sufferers with selfawareness of the adverse effects of Pulmonary TB disease.
\end{abstract}

Keywords: Pulmonary tuberculosis disease, health belief model, motivation

Copyright $@ 2021$ IIK STRADA Indonesia All right reserved.

This is an open-acces article distributed under the terms of the Creative Commons Attribution-ShareAlike 4.0 International License.

\section{INTRODUCTION}

Infectious diseases are health problems that have not been solved until now, one of these infectious diseases is tuberculosis (World Health Organization, 2015). Tuberculosis is a health problem, both in terms of mortality or mortality, and the incidence rate of disease or morbidity. Tuberculosis is also included in the SDGs program with the number 3, namely ensuring a healthy life and encouraging welfare for all people of all ages with the target of ending the tuberculosis epidemic (Kemenkes RI, 2018b). Tuberculosis has infected many people in Indonesia and the world. This 
disease began to be known by the world community since the 1882 bacterium mycobacterium tuberculosis introduced by Robert Koch in 1882 (PDPI, 2011). It also has a high fat content in cell membranes, causing it to become resistant to acids and slow growth of germs (Rafflesia, 2014).

People are very vulnerable to exposure to pulmonary tuberculosis because in Indonesia that does not pay attention to environmental conditions, such as lighting conditions, rarely open windows, humid and dusty environments (Irianti, T., Kuswandi., Yasin, M.N., \& Kusumaningtyas, 2016). Humans infected with the bacterium mycobacterium tuberculosis are transmitted and transmitted to other humans through a splash of phlegm that comes out when coughing, sneezing and while talking. Families have a greater risk of contracting tuberculosis because they cannot avoid contact with sufferers. Some other risk factors for tuberculosis include socioeconomic conditions, poor ventilation, poor nutrition and smoking and alcohol (Ernst, 2012). This makes tuberculosis sufferers increasing. Lack of motivation in preventing disease transmission and public awareness, especially small communities, namely family is the key in breaking the chain of transmission of pulmonary tuberculosis disease (Muna and Soleha, 2018).

Pulmonary tuberculosis (pulmonary TB) is a major health problem worldwide (Harries et al., 2005). As of 2011 there were 9 million new cases of tuberculosis, and more than 2 million people died from tuberculosis. All countries in the world account for tuberculosis cases, but the highest percentage occurs in Africa (30\%) and Asia (55\%), namely China and India accounted for 35\% of the total cases in Asia (Zijenah, 2018). Indonesia is a country that is included in the High Burden Countries, which is currently ranked 5th country with the highest tuberculosis burden in the world. The five countries with the largest number of such incidents are India, China, South Africa, Nigeria and Indonesia. The estimated prevalence of tuberculosis is 660,000 and the estimated incidence amounts to 430,000 new cases per year. The number of deaths from tuberculosis is estimated at 61,000 deaths per year (Director General of P2\&PL Ministry of Health, 2011).

According to the results of a survey by the Ministry of Health of the Republic of Indonesia (2011) on the prevalence of tuberculosis in 2019, knowledge, attitudes and behaviors show that $96 \%$ of families take care of family members suffering from tuberculosis and only $13 \%$ hide their existence. Although $76 \%$ of families have heard of tuberculosis and $85 \%$ know that tuberculosis can be cured, only $26 \%$ can mention the two main signs and symptoms of tuberculosis. The way tuberculosis is transmitted is understood by $51 \%$ of families and only $19 \%$ know that free tuberculosis drugs are available (Siswanto, Yanwirasti and Usman, 2015).

In a 2017 Word Health Organization (WHO) report, an estimated 8.7 million people contracted pulmonary tuberculosis and 1.4 million died. Southeast Asian countries account for $29 \%$ of tuberculosis cases worldwide (Sari, Mubasyiroh and Supardi, 2017). There are 460,000 new cases of pulmonary tuberculosis each year in Indonesia. Tuberculosis patients in 2019 in Indonesia reached 800,000-900,000 people (Ministry of Health RI, 2018). Seeing the high death rate due to pulmonary tuberculosis, WHO implemented a strategy that is Millennium Development Goals (MDGs).

Based on the results of a preliminary study conducted at the Gurah Health Center in Kediri, it is known that during 2019 there were 40 tuberculosis patients where 19 patients had BTA (+), 16 patients had BTA (-), and 5 patients had dropped out. While during 2015 there were 35 tb patients where 22 
patients had BTA (+), 13 patients had BTA (-), and no patients dropped out (Gurah Health Center, 2019).

Currently, the implementation of tuberculosis control efforts in Indonesia administratively under two Directorate General of the Ministry of Health, namely Bina Upaya Kesehatan, and P2PL (Subdit Tuberculosis under the Directorate General of P2PL). The development of public health center is under the Directorate General of Health Efforts and is the backbone of tuberculosis services with the direction of the tuberculosis subdivision, while the construction of hospitals is under the Directorate General of Health Efforts (Kemenkes RI, 2018a). There are many ways to overcome pulmonary tuberculosis transmission, especially in the role of local health workers, especially nurses in providing motivation with a health belief model approach.

The Health Belief Model is a cognitive model for identifying, predicting health behaviors, and explaining the causes of individual failures in undergoing disease prevention programs (Abraham and Sheeran, 2014). The main concepts in the health belief model are perceived vulnerability, perceived seriousness, perceived benefits and obstacles and cues to action. The effectiveness of the health belief model was proven by researchers in preventive behaviors such as vaccination against infectious diseases such as bruselosis, breast self-examination for early detection of cancer, and smoking cessation (Carpenter, 2010).

Families as the smallest units in the community play an important role in the recovery of patients. This perception is very important to determine whether the family is obedient or disobedient in carrying out health actions. Therefore, it is so important to assess the family's perception of tuberculosis, and if the family is still wrong in perceiving tuberculosis disease then health workers (nurses in particular) can make corrections to the concept of the disease and the services provided will be accepted by the sufferer to the maximum (Costa, 2020). The health belief model has a joint relationship in the healing program and severs the chain of transmission of pulmonary tuberculosis, so that the model has a positive impact and bias is carried out by health workers and families, as well as the surrounding community (Clarke et al., 2000).

Most people with pulmonary TB do not take precautions against the transmission of pulmonary tuberculosis (Kenedyanti and Sulistyorini, 2017). An influencing factor is the motivation in a person to take such actions in this case, namely to take precautions against the transmission of pulmonary tuberculosis. Motivation has a big part in improving supervision and encouragement to clients to independently prevent and deal with health problems.

Based on the description above, the perspective of society and family as the smallest unit is a very important basic system in the management of pulmonary TB disease, where healthy behaviors and health care are regulated, implemented, and secured. The family provides preventive health care and jointly cares for sick family members. Families have a primary responsibility to start and coordinate the services provided by health care professionals. Family is also an important element of society that must have efforts in improving health, if it wants to be free from tuberculosis.

Based on the above exposure, researchers are interested to research about "The influence of health belief model and motivation with the prevention of pulmonary tuberculosis transmission in Gurah Public Health Center Kediri Regency". 


\section{MATERIALS AND METHODS}

The design used in the study is correlational analytics with a cross sectional method approach. While the samples in this study are some people with pulmonary tuberculosis (TB) in Gurah Health Center with BTA (+) as many as 22 respondents. Variables in the study were divided into two, there are independent variable (health belief model and motivation) and dependent variable (prevention of pulmonary tuberculosis transmission). This research instrument uses questionnaires on each variable. The questionnaire used in the study is a health belief model and motivation questionnaire that has been conducted validity and reliability tests in Bendo Public Health Center. Validity test results show the number of each item of the questionnaire is more than $r$ counted and the Cronbach alpha value indicates a value of $p>0.70(p=0.780)$. The research was conducted in Gurah Public Health Center, Kediri Regency. Sampling is done with research sampling technique is total sampling. The population of 35 respondents consists of BTA (-) as many as 13 respondents and BTA(+) as many as 22 respondents. In this study the samples used were respondents with BTA (+) 22 respondents. Variable test analysis using bivariate test in the form of Spearman Rho test significant level $\alpha=0.05$, so as to answer the purpose of research.

\section{RESULTS}

Bivariate Analysis of Health Belief Model and Motivation Relationship with Prevention of Pulmonary Tuberculosis Transmission in Gurah Health Center, Kediri Regency

Table 1 Cross Tabulation of Health Belief Model Relationships with Prevention of Pulmonary Tuberculosis Transmission

\begin{tabular}{|c|c|c|c|c|c|c|c|c|c|}
\hline \multirow{3}{*}{ No. } & \multirow{3}{*}{ Health Belief Model } & \multicolumn{6}{|c|}{ Prevention of Pulmonary TB Transmission } & \multirow{2}{*}{\multicolumn{2}{|c|}{ Total }} \\
\hline & & \multicolumn{2}{|c|}{ Good } & \multicolumn{2}{|c|}{ Enough } & \multicolumn{2}{|c|}{ Les } & & \\
\hline & & $\mathbf{f}$ & $\%$ & f & $\%$ & $\mathbf{f}$ & $\%$ & f & $\%$ \\
\hline & Good & 2 & 9 & 0 & 0 & 0 & 0 & 2 & 9 \\
\hline 2. & Enough & 11 & 50 & 2 & 9 & 2 & 9 & 15 & 68 \\
\hline 3. & Less & 0 & 0 & 2 & 9 & 3 & 14 & 5 & 23 \\
\hline & Total & 14 & 59 & 4 & 18 & 5 & 23 & 22 & 100 \\
\hline
\end{tabular}

Source : Primary Data 2020

Table 2 Cross Tabulate Motivational Relationship with Prevention of Pulmonary Tuberculosis Transmission

\begin{tabular}{|c|c|c|c|c|c|c|c|c|c|c|}
\hline \multirow{3}{*}{ No. } & & \multirow{3}{*}{ Motivation } & \multicolumn{6}{|c|}{ Prevention of Pulmonary TB Transmission } & \multirow{2}{*}{\multicolumn{2}{|c|}{ Total }} \\
\hline & & & \multicolumn{2}{|c|}{ Strong } & \multicolumn{2}{|c|}{ Are } & \multicolumn{2}{|c|}{ Weak } & & \\
\hline & & & $\mathbf{f}$ & $\%$ & $\mathbf{f}$ & $\%$ & f & $\%$ & $\mathbf{f}$ & $\%$ \\
\hline 1. & Strong & & 2 & 9 & 0 & 0 & 0 & 0 & 2 & 9 \\
\hline 2. & Are & & 8 & 36 & 2 & 9 & 1 & 5 & 11 & 50 \\
\hline 3. & Weak & & 3 & 14 & 2 & 9 & 4 & 18 & 9 & 41 \\
\hline & & Total & 13 & 59 & 4 & 18 & 5 & 23 & 22 & 100 \\
\hline
\end{tabular}

Source : Primary Data 2020

Based on table 1 and 2 cross tabulation above obtained the results that if it has a good health belief model, then the prevention of disease transmission will also be good. As well as strong motivation, the prevention of disease transmission will also be good. From the results of the calculation to interpret how strong the relationship is in the form of words. Here's how to interpret data and correlation, among others (Nursalam, 2016): 
Table 3 Interpretation of Correlation Coefficients

\begin{tabular}{cc}
\hline Coefficient Interval & Correlation Level \\
\hline $0,00-0,199$ & Very Low \\
$0,20-0,399$ & Low \\
$0,40-0,599$ & Are \\
$0,60-0,799$ & Strong \\
$0,80-1,000$ & Very Strong \\
\hline
\end{tabular}

\section{Spearman's Rho Inter-Variable Analysis Results}

The results of spearman's Rho correlation calculation can be seen in the following table:

\section{Analysis of Health Belief Model Relationship with Prevention of Pulmonary Tuberculosis}

\section{Transmission}

Table 4 Relationship of Health Belief Model with Prevention of Pulmonary Tuberculosis Transmission

\begin{tabular}{|c|c|c|c|c|}
\hline & & & Health belief model & $\begin{array}{c}\text { Prevention of } \\
\text { Pulmonary Tuberculosis } \\
\text { Transmission } \\
\end{array}$ \\
\hline Spearman's rho & Health belief model & $\begin{array}{l}\text { Correlation } \\
\text { coefficient } \\
\text { sig. (2-tailed) } \\
\mathrm{N}\end{array}$ & $\begin{array}{r}1.000 \\
22\end{array}$ & $\begin{array}{r}0.643^{\prime \prime} \\
.001 \\
22\end{array}$ \\
\hline & $\begin{array}{l}\text { Prevention of } \\
\text { Pulmonary } \\
\text { Tuberculosis } \\
\text { Transmission }\end{array}$ & $\begin{array}{l}\text { Correlation } \\
\text { coefficient } \\
\text { sig. (2-tailed) } \\
\mathrm{N}\end{array}$ & $\begin{array}{r}0.643 ” \\
.001 \\
22\end{array}$ & 1.000 \\
\hline
\end{tabular}

** Correlation is significant at the. 0,01 level (2-tailed)

Based on the analysis obtained the influence of health belief model with the prevention of pulmonary tuberculosis transmission in Gurah Public Health Center district which has a sig value (2-tailed) $=0.05$ or $p=0.001$ and this indicates that $p<\alpha$, so that $\mathrm{H} 0$ is rejected and $\mathrm{H} 1$ is accepted, means there is a correlation between health belief model with the prevention of pulmonary TB transmission in Gurah Health Center Kediri district in 2020 and a coefficient correlation value of 0.643 which means the strength of the relationship belongs to the strong and positive category.

2. Analysis of Motivational Relationships with Prevention of Pulmonary TB Transmission

Table 5 Motivational Relationships with Prevention of Pulmonary TB Transmission

\begin{tabular}{|c|c|c|c|c|}
\hline \multirow[b]{2}{*}{ Spearman's rho } & \multirow[b]{2}{*}{ Motivation } & & Motivation & $\begin{array}{c}\text { Prevention of } \\
\text { Pulmonary Tuberculosis } \\
\text { Transmission } \\
\end{array}$ \\
\hline & & $\begin{array}{l}\text { Correlation } \\
\text { coefficient sig. } \\
\text { (2-tailed) } \\
\mathrm{N}\end{array}$ & $\begin{array}{r}1.000 \\
22\end{array}$ & $\begin{array}{r}.490, \\
.021 \\
22\end{array}$ \\
\hline & $\begin{array}{l}\text { P Prevention of } \\
\text { Pulmonary } \\
\text { Tuberculosis } \\
\text { Transmission } \\
\text { encegahan penularan } \\
\text { TB Paru }\end{array}$ & $\begin{array}{l}\text { Correlation } \\
\text { coefficient sig. } \\
\text { (2-tailed) } \\
\mathrm{N}\end{array}$ & $\begin{array}{r}.490 \% \\
.021 \\
22\end{array}$ & 1.000 \\
\hline
\end{tabular}

** Correlation is significant at the. 0,01 level (2-tailed) 
Based on the analysis, there is a linkage of motivational influence with the prevention of pulmonary tuberculosis transmission in Gurah Health Center Kediri regency which has a sig value (2-tailed) $=0.05$ or $\mathrm{p}=0.021$ and this indicates that $\mathrm{p}<$, so that $\mathrm{H} 0$ is rejected and $\mathrm{H} 1$ is accepted, means there is motivation with the prevention of pulmonary TB transmission in Gurah Public Health Center district in 2020 and a coefficient correlation value of 0.490 which means the strength of the relationship belongs to the moderate and positive categories.

\section{DISCUSSION}

Based on table 1, it is known that out of 22 respondents, most respondents have a health belief model with a "sufficient" category of 15 respondents (68\%), while others have a category of "less" as many as 5 respondents (23\%) and with the category of "good" as many as 2 respondents (9\%). This study is supported by general data in the form of almost half of respondents have primary school education (SD) as many as 9 respondents (41\%) and almost half of respondents did not work, which is as many as 7 respondents (32\%). Based on table 2, it is known that out of 22 respondents half have motivation with a "moderate" category of 11 respondents (50\%), while weak motivation as many as 9 respondents (41\%) and strong motivation of 2 respondents (9\%). Based on table 4 and 5 cross tabulation above obtained the results that if it has a good health belief model, then the prevention of disease transmission will also be good. As well as strong motivation, the prevention of disease transmission will also be good.

The stronger a person's belief that carrying out a behavior will give a positive result and prevent negative results, the more pleasant his attitude in carrying out the behavior, without forcing the individual to take the behavior (Fitriani, 2013). That high knowledge has the possibility to be active is 18 times greater than the low knowledge in the prevention of pulmonary tuberculosis (Rokhmah, 2013). Good attitudes are 8 times more likely to be active than those lacking in pulmonary tuberculosis prevention. High motivation is 15 times greater than low motivation in lung tuberculosis prevention (Ismah and Novita, 2017).

Based on the analysis obtained the association of the influence of health belief model with the prevention of pulmonary tuberculosis transmission in Gurah Public Health Center district which has a sig value $(2$-tailed $)=0.05$ or $\mathrm{p}=0.001$ and this indicates that $\mathrm{p}<0.05$, so that $\mathrm{H} 0$ is rejected and $\mathrm{H} 1$ is accepted, means there is a health belief model with the prevention of pulmonary TB transmission in Gurah Public Health Center district in 2020 and a coefficient correlation value of 0.643 which means the strength of the relationship belongs to the strong and positive category. The results of the analysis of the influence of health belief model with the prevention of pulmonary tuberculosis transmission, indicates a strong influence between the two variables. This shows that respondents' trust in the prevention of transmission in the surrounding environment, especially in the family can be prevented by the awareness of people with pulmonary tuberculosis to the potential of the spread of the disease. Sufferers and their families try to believe there are factors that can transmit the disease, so early protection must be done.

Based on the analysis obtained the association of motivational influence with the prevention of pulmonary tuberculosis transmission in Gurah Public Health Center district which has a sig value (2- 
tailed $)=0.05$ or $\mathrm{p}=0.021$ and this indicates that $\mathrm{p}<0.05$, so that $\mathrm{H} 0$ is rejected and $\mathrm{H} 1$ is accepted, means there is motivation with the prevention of pulmonary TB transmission in Gurah Public Health Center in 2020 and a coefficient correlation value of 0.490 which means the strength of the relationship belongs to the moderate and positive categories. The results of data analysis between motivation variables and prevention of transmission of pulmonary tuberculosis disease, which has an influence that can make the sufferer try to increase expectations on him to be more careful in making contact with the environment, both family and in the surrounding community. The effect on both variebel has a medium bond, because the motivation in people with pulmonary tuberculosis is too easy to change, considering the psychological of people with pulmonary tuberculosis adjusts to the symptoms and stigma of the family and the surrounding environment.

The family in an effort to stop the transmission of pulmonary tuberculosis disease is to always remind the sufferer not to throw phlegm in any place, in addition to preparing a special place for tuberculosis sufferers to remove phlegm. Disposing of phlegm is not indiscriminately one of the efforts to prevent the transmission of disease.

\section{CONCLUSION}

This study showed that the majority of respondents had the use of health belief models with a category of "sufficient" as many as 15 respondents $(68 \%)$. Half of respondents were motivated by the "moderate" category of 11 respondents (50\%). Most of the respondents had prevention of pulmonary TB behavior with a category of "good" as many as 13 respondents (59\%). There is an influence of health beliefe model with the prevention of pulmonary tuberculosis transmission in Gurah Public Health Center which has a sig value (2-tailed) $\mathrm{p}=0.001$. There is motivation with the prevention of pulmonary tuberculosis transmission in Gurah Public Health Center which has a sig value (2-tailed) $p$ $=0.021$.

\section{ACKNOWLEDGMENTS}

The author thanked the research funders, namely STIKes Bhakti Mulia, and thanked respondents for their valuable information and awareness to participate in this research.

\section{CONFLICTS OF INTEREST:}

The authors state that they have no conflict of interest.

\section{REFERENCES}

Abraham, C. and Sheeran, P. (2014) 'The health belief model', in Cambridge Handbook of Psychology, Health and Medicine, Second Edition. doi: 10.1017/CBO9780511543579.022.

Carpenter, C. J. (2010) 'A meta-analysis of the effectiveness of health belief model variables in predicting behavior', Health Communication. doi: 10.1080/10410236.2010.521906.

Clarke, V. A. et al. (2000) 'Unrealistic optimism and the health belief model', Journal of Behavioral Medicine. doi: 10.1023/A:1005500917875.

Costa, M. F. (2020) 'Health belief model for coronavirus infection risk determinants', Revista de 
Saude Publica. doi: 10.11606/S1518-8787.2020054002494.

Depkes RI (2018) 'Kementerian Kesehatan Republik Indonesia’, Kementerian Kesehatan RI.

Dirjen P2\&PL Kementerian Kesehatan RI (2011) 'Terobosan Menuju Akses Universal, Strategi Nasional Pengendalian TB di Indonesia 2010-2014', Stop TB.

Ernst, J. D. (2012) 'The immunological life cycle of tuberculosis', Nature Reviews Immunology. doi: $10.1038 /$ nri3259.

Fitriani, E. (2013) 'Faktor Resiko Yang Berhubungan Dengan kejadian Tuberkulosis Paru', Unnes Journal of Public Health. doi: 10.15294/ujph.v2i1.3034.

Harries, A. D. et al. (2005) 'Human resources for control of tuberculosis and HIV-associated tuberculosis', International Journal of Tuberculosis and Lung Disease.

Irianti, T., Kuswandi., Yasin, M.N., \& Kusumaningtyas, A. . . (2016) 'Buku Anti-Tuberkulosis', in Mengenal Anti-Tuberkulosis.

Ismah, Z. and Novita, E. (2017) 'Studi Karakteristik Pasien Tuberkulosis Di Puskesmas Seberang Ulu 1 Palembang', Unnes Journal of Public Health. doi: 10.15294/ujph.v6i4.15219.

Kemenkes RI (2018a) Infodatin Tuberkulosis, Kementerian Kesehatan RI.

Kemenkes RI (2018b) Tuberkulosis ( TB ), Tuberkulosis.

Kenedyanti, E. and Sulistyorini, L. (2017) 'Analisis Mycobacterium Tuberkulosis dan Kondisi Fisik Rumah dengan Kejadian Tuberkulosis Paru', Jurnal Berkala Epidemiologi.

Muna, L. and Soleha, U. (2018) 'Motivasi Dan Dukungan Sosial Keluarga Mempengaruhi Kepatuhan Berobat Pada Pasien Tb Paru Di Poli Paru Bp4 Pamekasan', Journal of Health Sciences. doi: 10.33086/jhs.v7i2.506.

Nursalam (2016) Metodologi Penelitian Ilmu Keperawatan. 4th edn. Jakarta: Salemba Medika.

PDPI (2011) Pedoman Penatalaksanaan TB (Konsensus TB), Perhimpunan Dokter Paru Indonesia. doi: 10.5860/CHOICE.41-4081.

Rafflesia, U. (2014) 'Model Penyebaran Penyakit Tuberkulosis (TBC)', Gradien.

Rokhmah, D. (2013) 'Gender dan Penyakit Tuberkulosis: Implikasinya Terhadap Akses Layanan Kesehatan Masyarakat Miskin yang Rendah', Kesmas: National Public Health Journal. doi: 10.21109/kesmas.v7i10.3.

Sari, I. D., Mubasyiroh, R. and Supardi, S. (2017) 'Hubungan Pengetahuan dan Sikap dengan Kepatuhan Berobat pada Pasien TB Paru yang Rawat Jalan di Jakarta Tahun 2014', Media Penelitian dan Pengembangan Kesehatan. doi: 10.22435/mpk.v26i4.4619.243-248.

Siswanto, I. P., Yanwirasti, Y. and Usman, E. (2015) 'Hubungan Pengetahuan dan Dukungan Keluarga dengan Kepatuhan Minum Obat Anti Tuberkulosis di Puskesmas Andalas Kota Padang', Jurnal Kesehatan Andalas. doi: 10.25077/jka.v4i3.354.

World Health Organization (2015) Global Tuberculosis Report, Blood. doi: 9789241564502.

Zijenah, L. S. (2018) 'The World Health Organization Recommended TB Diagnostic Tools', in Tuberculosis. doi: 10.5772/intechopen.73070. 